\title{
COMPLEXES OF FLUCONAZOLE WITH ALANINE, LYSINE AND THREONINE: MASS SPECTROMETRY AND THEORETICAL MODELING
}

\author{
Chagovets W $\otimes$, Starodubtseva NL, Frankevich VE
}

National Medical Research Center for Obstetrics, Gynecology and Perinatology named after Academician V. I. Kulakov, Moscow, Russia

Investigation of the triazole-derived drugs action mechanisms and understanding of their affinity and specificity molecular basis may contribute to the new drugs development. The study was aimed to investigate the triazoles class representative (fluconazole) complexes with amino acids using mass spectrometry, molecular dynamics and ab initio quantum chemistry calculations. During the experimental study, the fluconazole, alanine, lysine and threonine solutions were analyzed by electrospray ionization mass spectrometry and tandem mass spectrometry. The molecular dynamics modeling of the fluconazole-amino acid complexes was performed using the CHARMM force field. The quantum chemistry calculations of the complexes structure and energy parameters were carried out using the density-functional theory by B3LYP calculations ( $3-21 G$ and $6-311++G^{* *}$ basis sets). Mass spectra indicated that fluconazole formed stable complexes with amino acids in the 1: 1 stoichiometric ratio. In accordance with the tandem mass spectrometry with varying fluconazole-amino acid associates ion fragmentation energy, the following sequence was obtained: [Fluc $+\mathrm{Ala}+\mathrm{H}]^{+}<[\text {Fluc }+\mathrm{Lys}+\mathrm{H}]^{+}<[\text {Fluc }+\mathrm{Thr}+\mathrm{H}]^{+}$. The fluconazole-amino acid interaction energy values resulting from the quantum chemistry calculations formed the sequence similar to that obtained by experiment. Thus, as seen in the case of fluconazole-amino acid complexes, it is possible to combine the experimental mass spectrometry studies with quantum chemical modeling for the complexes properties assessment.

Keywords: mass spectrometry, molecular dynamics, quantum chemistry, pharmacology, antifungal drugs

Funding: the study was carried out as a part of the convention № 05.604.21.0241, Development of a Technology for Personalized Treatment of Mothers and Newborns With Infectious and Inflammatory Diseases Caused by Multi-resistant Strains of Microorganisms, Based on Genotyping of Pathogens and Therapeutic Drug Monitoring of Antimicrobial Drugs (item 1,2, queue 1), of the Ministry of Science and Higher Education of the Russian Federation. Programme for Research and Development in Priority Areas of Development of the Russian Scientific and Technological Complex for 2014-2020. Project ID: RFMEFI60419X0241.

Author contribution: Chagovets W, Frankevich VE, Starodubtseva NL — study concept and design, data processing; Chagovets W — statistical analysis; Chagovets W, Starodubtseva NL — manuscript writing; Frankevich VE — editing.

Compliance with ethical standards: the study was approved by the Ethics Committee of Ural State Medical University (Protocol № $1451 / 19$ dated September 20, 2019). The patient gave informed consent to participate in the study.

$\triangle$ Correspondence should be addressed: Vitaliy V. Chagovets Oparina, 4, Moscow, 117198; vvchagovets@gmail.com

Received: 22.07.2020 Accepted: 13.08.2020 Published online: 22.08.2020

DOI: $10.24075 /$ brsmu.2020.048

\section{МАСС-СПЕКТРОМЕТРИЧЕСКОЕ ИССЛЕДОВАНИЕ И ТЕОРЕТИЧЕСКОЕ МОДЕЛИРОВАНИЕ КОМПЛЕКСОВ ФЛУКОНАЗОЛА С АЛАНИНОМ, ЛИЗИНОМ И ТРЕОНИНОМ}

\section{В. В. Чаговец $\bowtie$, Н. Л. Стародубцева, В. Е. Франкевич}

Национальный медицинский исследовательский центр акушерства, гинекологии и перинатологии имени В. И. Кулакова, Москва, Россия

Изучение механизмов действия препаратов триазола и понимание молекулярной основы их аффинности и специфичности может быть использовано для рациональной разработки новых лекарственных средств. Целью работы было изучить комплексы представителя класса триазолов флуконазола с аминокислотами с помощью масс-спектрометрии, молекулярной динамики и квантово-химических ab initio расчетов. В ходе экспериментального исследования с помощью масс-спектрометрии с электрораспылительной ионизацией и тандемной масс-спектрометрии были проанализированы растворы флуконазола, аланина, лизина и треонина. Молекулярно-динамическое моделирование комплексов флуконазола с аминокислотами проводили с использованием силового поля СНАRММ. Квантово-химические расчеты структуры и энергетических параметров комплексов проводили на уровне теории функционала плотности с использованием функций BЗLYP с базисом 3-21G и 6-311++G*. Масс-спектры показали, что флуконазол образует стабильные комплексы с аминокислотами в стехиометрическом соотношении 1 : 1. По результатам тандемной масс-спектрометрии с варьированием энергии фрагментации ионов-ассоциатов фрлуконазола с аминокислотами построен следующий ряд: [Fluc + Ala $+\mathrm{H}]^{+}<[\text {Fluc }+ \text { Lys }+\mathrm{H}]^{+}<[\text {Fluc }+ \text { Thr }+\mathrm{H}]^{+}$. Получившиеся в результате квантово-химических расчетов энергии взаимодействия между флуконазолом и аминокислотой образуют ряд, аналогичный полученному по экспериментальным данным. Таким образом, на примере комплексов флуконазола с аминокислотами продемонстрирована возможность комбинирования экспериментальных масс-спектрометрических исследований и квантово-химического моделирования для изучения свойств таких комплексов.

Ключевые слова: масс-спектрометрия, молекулярная динамика, квантовая химия, фармакология, противогрибковые препараты

Финансирование: работа выполнена в рамках соглашения № 05.604.21.0241 «Разработка технологии персонализированного лечения матерей и новорожденных с инфекционно-воспалительными заболеваниями, вызванными мультирезистентными штаммами микроорганизмов, на основании генотипирования возбудителей и терапевтического лекарственного мониторинга антимикробных препаратов» (мероприятие 1,2, очередь 1) Министерства науки и высшего образования РФ. Программа: «Исследование и разработка по приоритетным направлениям развития научнотехнологического комплекса России на 2014-2020 годы». Уникальный идентификатор проекта RFMEFI60419X0241.

Вклад авторов: В. В. Чаговец, В. Е. Франкевич, Н. Л. Стародубцева - концепция и дизайн исследования, обработка материала; В. В. Чаговец статистическая обработка данных; В. В. Чаговец, Н. Л. Стародубцева - написание текста; В. Е. Франкевич - редактирование.

Соблюдение этических стандартов: исследование одобрено этическим комитетом Уральского государственного медицинского университета (протокол № 1451/19 от 20 сентября 2019 г.). Получено добровольное информированное согласие на участие пациента в научном исследовании.

$\bigotimes$ Для корреспонденции: Виталий Викторович Чаговец ул. Академика Опарина, д. 4, г. Москва, 117198; vvchagovets@gmail.com

Статья получена: 22.07.2020 Статья принята к печати: 13.08.2020 Опубликована онлайн: 22.08.2020

DOI: $10.24075 /$ vrgmu.2020.048 
Cytochrome P450 sterol 14 $\alpha$-demethylase (CYP51), the product of ERG11 gene, is a target site for triazoles. The CYP51 enzyme converts lanosterol into ergosterol being a part of the fungal cell membrane main component biosynthesis pathway [1]. Ergosterol biosynthesis inhibition slows down the mycelia cells growth due to toxic steroids (such as methylated sterols) accumulation [2-4], violating the membrane integrity, fluidity and permeability [5]. Fluconazole (Fluc) acts as a competitive inhibitor of CYP51. Currently, it is effective for treatment of many fungal infections.

The development of new classes of compounds is necessary for the treatment of mycoses and antifungal drugs resistance. Antifungal drugs are relatively difficult to develop compared to antibacterial drugs due to eukaryotic type of cells. Besides, the triazole derived antifungal agents (such as fluconazole) eventually become insufficient for treatment of many infections. The need to develop new medicinal products is an incentive to the triazole drugs inhibition molecular mechanisms study enabling to understand the molecular basis for the fluconazole affinity and specificity.

Previously, the molecular modeling was used to search for pyrazole analogues. The search was based on the CYP51-Ca protein structure [6, 7]. Furthermore, the molecular modeling made it possible to investigate the features and patterns of various inhibitors interaction with CYP51 [8], as well as the role of mutations in the stability and affinity of enzyme binding [9, 10]. Molecular dynamics also made it possible to study the factors of the fluconazole greater affinity for fungal enzymes rather than mycobacterial and human orthologs [11]. A review of the modeling strategies used to design the P450 binding ligands was recently published [12].

Database analysis revealed a number of conserved amino acids (AA) $[13,14]$. Of those, three amino acids playing a vital part in protein-inhibitor biding were selected using the molecular dynamics modeling: threonine (Thr77), alanine (Ala258) and lysine (Lys454) [8].

Although the molecular mechanics studies may help to predict amino acids involved in the protein-inhibitor complex assembly, it is important to have a number of experimental methods allowing one to verify the resulting model. Experimental approach using electrospray ionization mass spectrometry (ESIMS) may be a powerful means for the host-guest complexation forecasting and complementary theoretical calculation using the molecular mechanical models.

ESI-MS is widely used for studying of noncovalent interactions between proteins and other biomolecules [1517]. The soft ionization procedure permits the molecular complexes to retain "conformational memory" of their solution state structures in the gas phase [18]. Over the past decades, the rapidly increasing number of papers on the noncovalent interactions assessment using MS indicated that MS had become an important method due to high throughput, sensitivity and small sample volumes [19]. MS was used for the host-guest complexation assessment [20-25].

The noncovalent interactions between fluconazole and amino acids as elementary stages of the protein-inhibitor complex formation have not been previously studied.

The study was aimed to investigate the fluconazole-amino acid complexes in the gas phase using ESI-MS, as well as to assess the complexes structural and energy parameters using molecular dynamics and ab initio quantum chemistry methods.

\section{METHODS}

Fluconazole (Fluc), alanine (Ala), lysine (Lys), threonine (Thr), and methanol (HPLC grade) were obtained from Merck
(Merck; Germany). Deionized water was prepared using the Milli-Q Reference Water Purification System (Merck; France). Each amino acid and fluconazole stock solution was prepared in methanol at a concentration of $10 \mathrm{mmol} / \mathrm{mL}$. For mass spectrometry of individual compounds, the stock solutions were diluted with water to a concentration of $1 \mathrm{mmol} / \mathrm{mL}$. The samples for the fluconazole-amino acid complexes analysis by tandem mass spectrometry were prepared by mixing the stock solutions of fluconazole and one of the amino acids in the $1: 1$ ratio $(v: v)$. The solutions so obtained were diluted with water to a concentration of $1 \mathrm{mmol} / \mathrm{mL}$ for each component and stirred during $30 \mathrm{~s}$. The sample for comparison of the fluconazoleamino acid complexes relative peak intensities was prepared by mixing the equal volumes of fluconazole, alanine, lysine and threonine stock solutions. The resulting solution was diluted with water to a concentration of $1 \mathrm{mmol} / \mathrm{mL}$ for each component and stirred during $30 \mathrm{~s}$. All samples were prepared at room temperature.

The experiment was carried out using the Maxislmpact hybrid quadrupole time-of-flight (QTOF) mass spectrometer (BrukerDaltonics; Germany). The following parameters were used in the positive ion mode: mass range $(\mathrm{m} / \mathrm{z})$ 50-1000, needle voltage $4.5 \mathrm{kV}$, nebulizer gas pressure 0.6 bar, drying gas flow rate $5.0 \mathrm{~L} / \mathrm{min}$, drying gas temperature $200{ }^{\circ} \mathrm{C}$. The tandem mass spectrometry experiments were carried out using the isolation window $3 \mathrm{~m} / \mathrm{z}$ and the collision energy variation. The sample was injected directly using the KD Scientific syringe pump (KD Scientific; USA), the flow rate was $3 \mu \mathrm{L} / \mathrm{min}$.

The molecular dynamics study of the Fluc + AA complexes was performed using the NAMD software [26]. The force field for the studied complexes modeling was created using the CHARMM General Force-Field (v3.1) basis [27, 28]. The types of atoms and partially the charges of the fluconazole atoms were selected by analogy. The missing parameters of bonds, angles and dihedral angles, as well as the missing charges of the fluconazole atoms were optimized using the Force Field Toolkit (ffTK), the VMD software plugin [26].

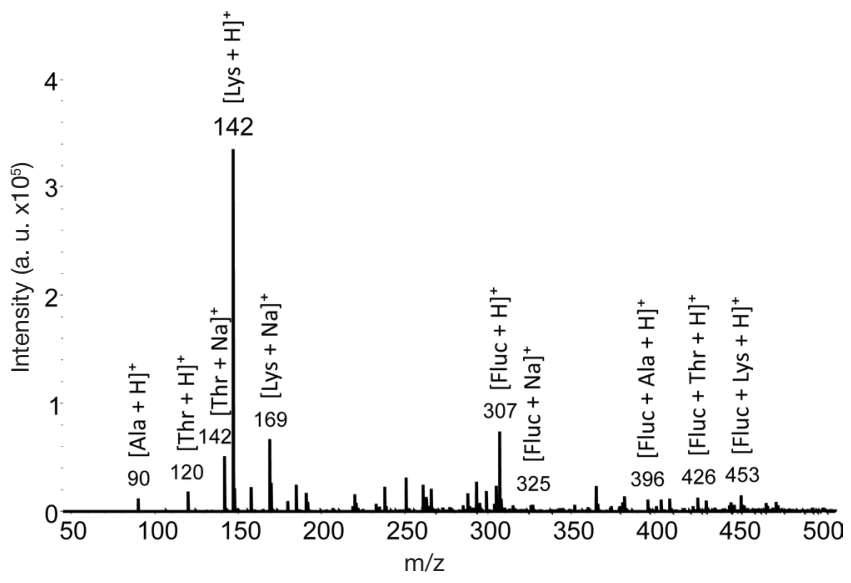

Fig. 1. Positive ion mass spectrum of the sample containing fluconazole, alanine threonine and lysine

Table 1. Fluconazole-amino acid complexes characteristics

\begin{tabular}{|l|c|c|c|}
\hline \multicolumn{1}{|c|}{ Amino acid } & I, a.u. ${ }^{1}$ & CE $_{50}$, эV $^{2}$ & $\begin{array}{c}\text { B3LYP/6-311++G** } \\
\mathrm{IE}, \mathrm{kJ} / \mathrm{mol}^{3}\end{array}$ \\
\hline Ala & 15061 & 23 & -56.8226463 \\
\hline Lys & 17540 & 25 & -65.600743 \\
\hline Thr & 18325 & 29 & -97.663349 \\
\hline
\end{tabular}

Note: ${ }^{1}$ - mass spectral complex peak intensity, au (Fig. 1 ); ${ }^{2}$ — energy needed for the tandem mass spectral precursor ion peak intensity reduction by $50 \%{ }^{3}$ interaction energy calculated by quantum chemical method B3LYP/6-311++G** 


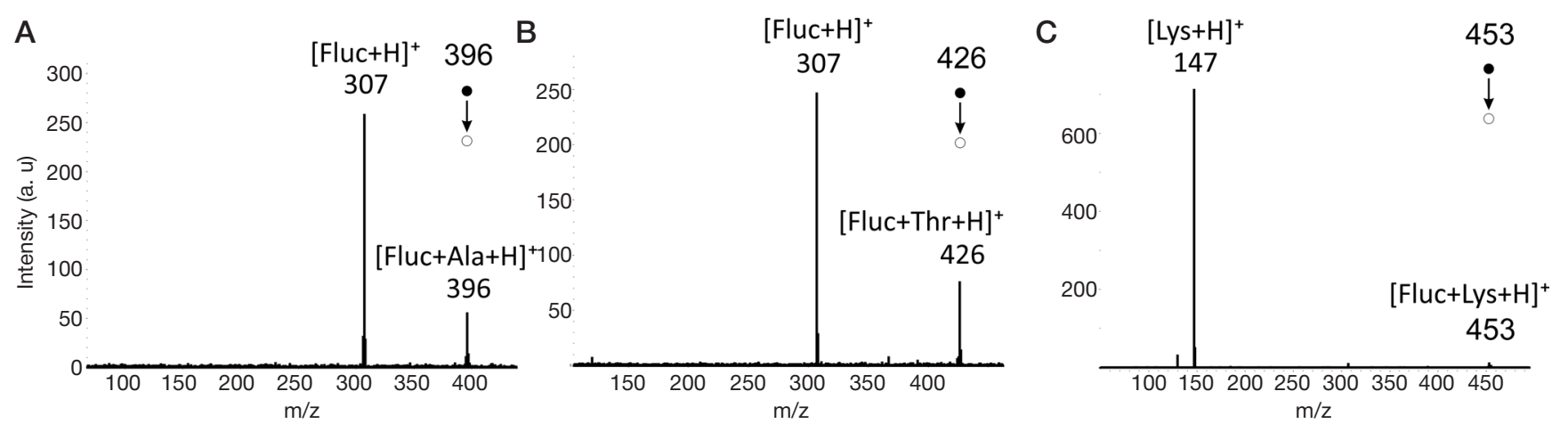

Fig. 2. Tandem mass spectra of fluconazole complexes with alanine $(\mathbf{A})$, threonine $(\mathbf{B})$ and lysine $(\mathbf{C})$ acquired using the positive ion mode

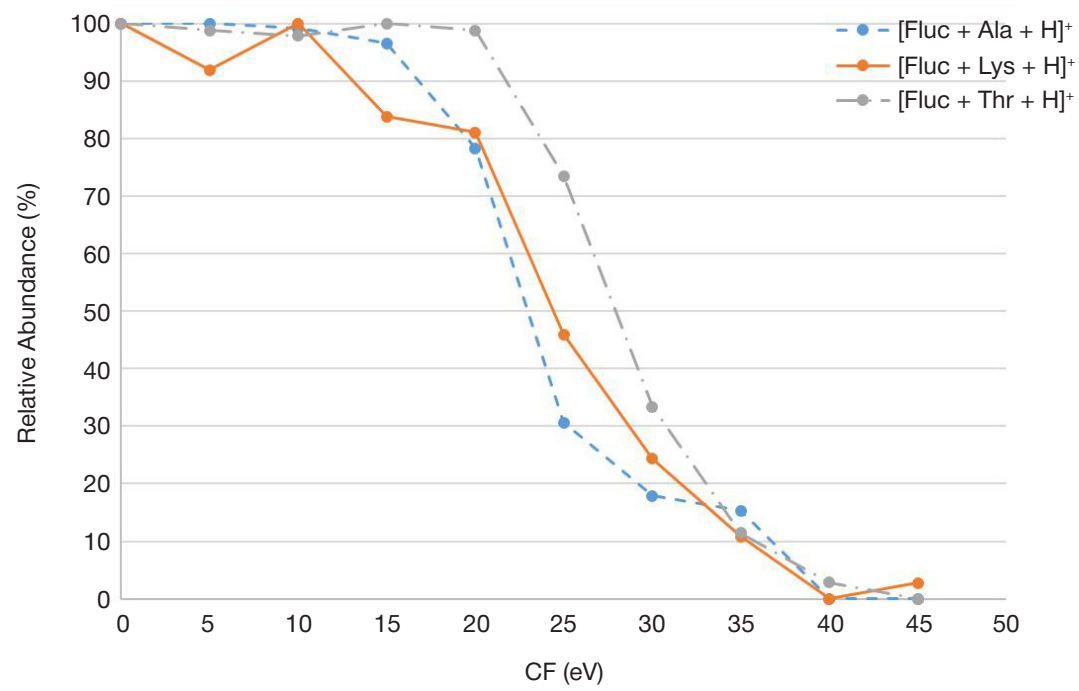

Fig. 3. Correlation between the fluconazole-amino acid complex precursor ion peak relative intensity and the collision energy (CE)

The quantum chemistry calculations of the fluconazoleamino acid complexes structure and energy parameters were performed using the GAMESS software package [29]. The complexes geometry optimization aimed at structural and energy properties study was carried out using the densityfunctional theory (DFT) by B3LYP calculations (3-21G and $6-311++G^{* *}$ basis sets with diffuse and polarization functions).

\section{RESULTS}

During the ESI-MS analysis of individual amino acids, the peaks corresponding to protonated and sodiated amino acids were identified. ESI-MS experiments with aqueous solutions containing both amino acid and fluconazole revealed the associates of amino acid and drug molecules, which indicated the sufficient stability of such complexes in the gas phase.

Fig. 1 provides the positive ion ESI mass spectrum of the aqueous solution containing all three amino acids and fluconazole at equimolar concentrations. The possibility of the associates formation is indicated by the following peaks: $[\text { Fluc }+\mathrm{Ala}+\mathrm{H}]^{+}(\mathrm{m} / \mathrm{z} \text { 396), [Fluc + Lys }+\mathrm{H}]^{+}(\mathrm{m} / \mathrm{z}$ 453) and $[\text { Fluc }+\mathrm{Thr}+\mathrm{H}]^{+}(\mathrm{m} / \mathrm{z} 426)$. Taking into account the corresponding peaks intensities, the following sequence can be formed (Table 1): $[\text { Fluc }+\mathrm{Ala}+\mathrm{H}]^{+}<[\text {Fluc }+\mathrm{Thr}+\mathrm{H}]^{+}<[\text {Fluc }+\mathrm{Lys}+\mathrm{H}]^{+}$. Since the mass spectral peaks intensity is in proportion to the number of corresponding ions reaching the detector, it can be assumed that the described sequence is also valid for the interaction energy of the complex. However, in addition to stability, the intensity of the associate ion is also contributed by its ionization efficiency, stability of individual components of the complex, etc. For the additional experimental assessment of the complexes stability and interaction energy, the tandem mass spectra obtained as a result of the studied associates collision-induced dissociation have been acquired and analyzed. Fig. 2 provides the complexes [Fluc $+\mathrm{Ala}+\mathrm{H}^{+}$(Fig. 2A), [Fluc + Thr $\left.+\mathrm{H}\right]^{+}$(Fig. 2B) and [Fluc + Lys $+\mathrm{H}]^{+}$(Fig. 2C) fragmentation mass spectra. The complexes peaks, as well as the complexes fragments peaks resulting from protonated fluconazole (in case of alanine and threonine associates fragmentation) and protonated lysine (in case of fluconazole associate fragmentation) have been identified in the mass spectra. Thus, at this stage, it can be concluded that the studied complexes fragmentation proceeds along two basic lines: either the neutral amino acid, or the neutral fluconazole loss. Apparently, that is due to the described molecules different proton affinity. To quantify the studied complexes stability, the peak intensities of the tandem mass spectra with the collision energy variation have been analyzed. Fig. 3 provides the correlation between the intensity of the precursor ion and the collision energy. The relative stability of fluconazole and various amino acids associates was evaluated by comparison of energy needed for the precursor ion peak intensity reduction by $50 \%$. These values were 23,25 and $29 \mathrm{eV}$ for the studied complexes containing alanine, lysine and threonine respectively (Table 1).

Thus, in the mass spectra of the fluconazole and alanine, threonine, lysine containing solutions the $[\text { Fluc }+\mathrm{AA}+\mathrm{H}]^{+}$ clusters were identified. Since the experimental evaluation of the complexes stability was possible, it was of interest to estimate the energy of fluconazole interaction with each of the studied amino acids, which was the subject of the molecular dynamics modeling and quantum chemical calculations described below. 
A

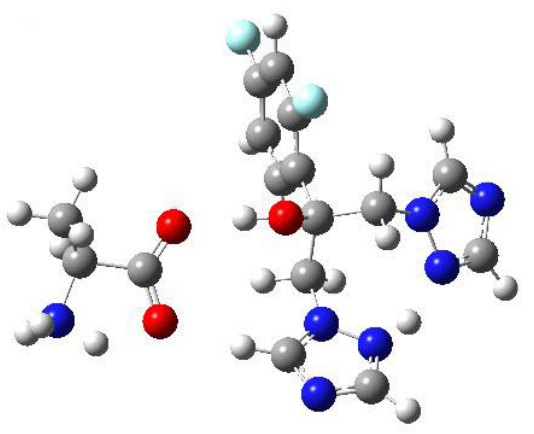

B

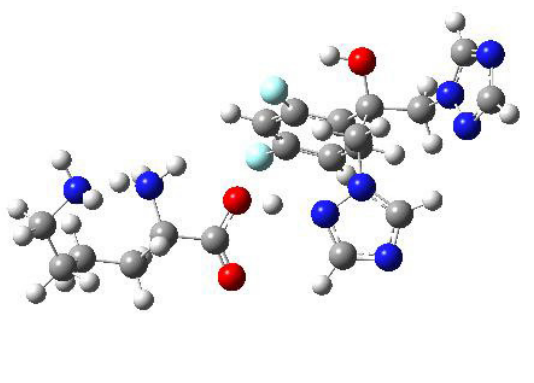

C

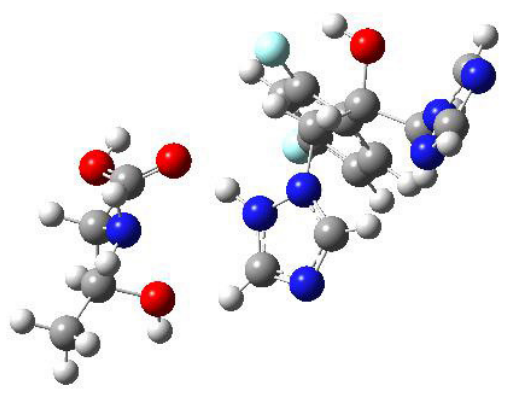

Fig. 4. Structure of fluconazole complexes with alanine $(\mathbf{A})$, lysine $(\mathbf{B})$ and threonine $(\mathbf{C})$ optimized by the $B 3 L Y P / 6-311++G^{* *}$ method

Table 2. Energy values for complex components and fluconazole-amino acid complexes; interaction energy values obtained by quantum chemical methods B3LYP/3-21 and $B 3 L Y P / 6-311++G^{* *}$

\begin{tabular}{|l|c|c|c|c|c|}
\hline \multicolumn{1}{|c|}{ Amino acid } & $E_{A B}$ (Fluc + AA), a.u. & $E_{A}$ (Fluc), a.u. & $E_{B}(A A)$, a.u. & IE, a.u. & IE, kJ/mol \\
\hline \multicolumn{7}{|c|}{ B3LYP/3-21 } \\
\hline Ala & -1422.2762 & -1100.264222 & -321.9574674 & -0.0544686 & -143.007 \\
\hline Lys & -1594.6453 & -1100.238944 & -494.3018987 & -0.1044502 & -274.234 \\
\hline Thr & -1536.1547 & -1100.238944 & -435.8476107 & -0.0681227 & -178.856 \\
\hline \multicolumn{7}{|c|}{ B3LYP/3-311++G* } \\
\hline Ala & -1430.53104 & -1106.65334 & -323.85606 & -0.02164 & -56.82 \\
\hline Lys & -1603.88596 & -1106.28645 & -497.57453 & -0.02499 & -65.60 \\
\hline Thr & -1545.09491 & -1106.63517 & -438.42255 & -0.03720 & -97.66 \\
\hline
\end{tabular}

The initial structure selection plays a vital part in the molecular geometry optimization by quantum chemistry. Since both amino acids and fluconazole have a large number of degrees of freedom and are conformationally mobile, in our study, the selection of the initial structure for quantum-chemical calculations was carried out using molecular dynamics by simulated annealing. The selection of the molecule (fluconazole or amino acid) being a proton acceptor was performed based on the tandem mass spectra (see Fig. 2). In the [Fluc + Ala $+\mathrm{H}^{+}$and $[\text {Fluc }+\mathrm{Thr}+\mathrm{H}]^{+}$complexes the fluconazole was protonated. In the [Fluc + Lys $+\mathrm{H}]^{+}$complex the proton was localized at the lysine. The resulting structures obtained by simulated annealing were optimized using the B3LYP method (first with $3-21 \mathrm{G}$ basis set, and then with $6-311++\mathrm{G}^{* *}$ basis set). The complex structures obtained by optimization are provided in Fig. 4. In the [Fluc $+\mathrm{Ala}+\mathrm{H}]^{+}$and $[\text {Fluc }+\mathrm{Thr}+\mathrm{H}]^{+}$ complexes the geometry optimization led to the proton shift towards fluconazole. In the [Fluc + Lys $+\mathrm{H}]^{+}$complex the proton was localized at the lysine, which was consistent with the hypothesis announced based on the experimental data. Such amino acids behavior might be due to amino acids and fluconazole different proton affinity, as well as to pl value, which was 9.74 for lysine, and 6 and 5.6 for alanine and threonine respectively. Based on the modeling, the complex formation energies were calculated using the formula $I E=E_{A B}-E_{A}-$ $E_{B}$, where $E_{A B}$ was the complex energy, $E_{A}$ and $E_{B}$ were the complex components energies. Table 2 provides energy values obtained by quantum chemistry calculations using the B3LYP/3-21 and B3LYP/6-311++G** methods. The interaction energies between the components of the complex calculated using the B3LYP/6-311++ $G^{* *}$ method matched the sequence experimentally obtained. When using the B3LYP/3-21 method, the energy of fluconazole interaction with lysine was higher than that with threonine. That may indicate the importance of using diffuse and polarization functions when modeling the noncovalent complexes.

\section{DISCUSSION}

Previously, the importance of understanding the range of amino acids involved in binding of triazine compounds and the character of interactions determining the stability of the protein-drug complexes was shown [11]. The same paper provided the comparison of fluconazole interactions with various CYP51 enzymes. In such complexes, the interaction energy resulted from the competitive binding of ligand with amino acid residues of the protein, heme and water molecules. The protein-fluconazole binding proved to be more effective in mitochondrial CYP51 due to polar interaction with the arginine residue. However, in fungal enzymes these interactions are substituted by ligand-heme interactions, which compensate for the loss of the polar bond and result in the more energetically favored binding. Therefore, the development of ligand with increased specificity to fungal enzymes should focus on the strengthening the polar ligandheme interactions. The larger hydrophobic ligands are probably best suited to target the mycobacterial and human enzymes [11]. Such studies demonstrate the importance of understanding and considering the interactions between the drug and the various components of the target. This paper provides the approach, which may be used at the early stages of the new drugs development, making it possible to estimate the drug-amino acid complexes stability both from the experimental and theoretical point of view.

\section{CONCLUSION}

ESI-MS and molecular dynamics were used for the study of fluconazole-amino acid interactions, which, according to literary sources, played a vital part in the protein-inhibitor binding. The noncovalent complexes turned out to be stable in the gas phase, which made it possible to identify the corresponding signals in the mass spectra. Tandem mass spectrometry with 
varying collision energy was used for the studied complexes stability assessment. The following stability sequence was obtained: $[\text { Fluc }+\mathrm{Ala}+\mathrm{H}]^{+}(23 \mathrm{eV})<[\text { Fluc }+ \text { Lys }+\mathrm{H}]^{+}(25 \mathrm{eV})$ $<$ [Fluc $+\mathrm{Thr}+\mathrm{H}]^{+}(29 \mathrm{eV})$. Molecular dynamics and quantum chemical modeling made it possible to define the complexes structure and interaction energy. The interaction energy values determined using the B3LYP/6-311++ $\mathrm{G}^{* *}$ method formed the associates stability sequence similar to that obtained by experiment. Such approach combining the experimental mass spectrometry studies and the quantum chemical modeling may be used at the early stages of the new drugs development, and to search for the drug action molecular mechanisms.

\section{References}

1. Balding PR, Porro CS, McLean KJ, Sutcliffe MJ, Maréchal JD, Munro AW, et al. How do azoles inhibit cytochrome P450 enzymes? A density functional study. J Phys Chem A. 2008; 112 (50): 12911-8.

2. Lupetti A, Danesi R, Campa M, Tacca M Del, Kelly S. Molecular basis of resistance to azole antifungals. Trends Mol Med. 2002; 8 (2): 76-81.

3. Marichal P, Gorrens J, Laurijssens L, Vermuyten K, Van Hove C, Le Jeune $L$, et al. Accumulation of 3-ketosteroids induced by itraconazole in azole- resistant clinical Candida albicans isolates. Antimicrob Agents Chemother. 1999; 43 (11): 2663-70.

4. White TC, Marr KA, Bowden RA. Clinical, cellular, and molecular factors that contribute to antifungal drug resistance. Clin Microbiol Rev. 1998; 11 (2): 382-402.

5. Shapiro RS, Robbins N, Cowen LE. Regulatory Circuitry Governing Fungal Development, Drug Resistance, and Disease. Microbiol Mol Biol Rev. 2011; 75 (2): 213-267.

6. Doğan İS, Saraç S, Sari S, Kart D, Eşsiz Gökhan Ş, Vural İ, et al. New azole derivatives showing antimicrobial effects and their mechanism of antifungal activity by molecular modeling studies. Eur J Med Chem. 2017; 130: 124-38.

7. Jacob K S, Ganguly S, Kumar P, Poddar R, Kumar A. Homology model, molecular dynamics simulation and novel pyrazole analogs design of Candida albicans CYP450 lanosterol $14 \alpha$-demethylase, a target enzyme for antifungal therapy. J Biomol Struct Dyn. 2017; 35 (7): 1446-63.

8. Gao P, Cui YL, Wu RL. Molecular dynamic modeling of CYP51B in complex with azole inhibitors. J Biomol Struct Dyn. 2018; 36 (6): 1511-9.

9. Keighobadi M, Emami S, Lagzian M, Fakhar M, Rafiei A, Valadan R. Molecular modeling and structural stability of wild-type and mutant CYP51 from leishmania major: In vitro and in silico analysis of a laboratory strain. Molecules. 2018; 23 (3). DOI: 10.3390/ molecules23030696.

10. Vijayakumar S, Das P. Structural, molecular motions, and freeenergy landscape of Leishmania sterol-14 $\alpha$-demethylase wild type and drug resistant mutant: a comparative molecular dynamics study. J Biomol Struct Dyn. 2019; 37 (6): 1477-93.

11. Honorato Siqueira T, Martínez L. Molecular simulations of fluconazole-mediated inhibition of sterol biosynthesis. J Biomol Struct Dyn. 2020; 38 (6): 1659-69.

12. Kontoyianni M, Lacy B. Toward Computational Understanding of Molecular Recognition in the Human Metabolizing Cytochrome P450s. Curr Med Chem. 2018; 25 (28): 3353-73.

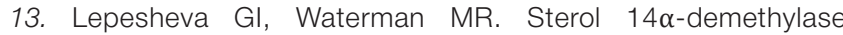
cytochrome P450 (CYP51), a P450 in all biological kingdoms. Biochim Biophys Acta — Gen Subj. 2007; 1770 (3): 467-77.

14. Lepesheva Gl, Waterman MR. Structural basis for conservation in the CYP51 family. Biochim Biophys Acta - Proteins Proteomics. 2011; 1814 (1): 88-93.

15. Loo JA. Studying noncovalent protein complexes by electrospray ionization mass spectrometry. Mass Spectrom Rev. 1997; 16 (1): 1-23.

16. Pramanik BN, Bartner PL, Mirza UA, Liu YH, Ganguly AK. Electrospray ionization mass spectrometry for the study of noncovalent complexes: An emerging technology. J Mass Spectrom. 1998; 33 (10): 911-20.

17. Loo JA. Electrospray ionization mass spectrometry: A technology for studying noncovalent macromolecular complexes. Int J Mass Spectrom. 2000; 200 (1-3): 175-86.

18. Ray SS, Singh SK, Balaram P. Sulfonate (ANS) Binding to Proteins. Data Process. 2001; 0305 (01).

19. Zhang S, Van Pelt CK, Wilson DB. Quantitative determination of noncovalent binding interactions using automated nanoelectrospray mass spectrometry. Anal Chem. 2003; 75 (13): 3010-8.

20. Tjernberg A, Carnö S, Oliv F, Benkestock K, Edlund PO, Griffiths WJ, et al. Determination of dissociation constants for protein-ligand complexes by electrospray ionization mass spectrometry. Anal Chem. 2004; 76 (15): 4325-31.

21. Benkestock K. Electrospray lonization Mass Spectrometry for Determination of Noncovalent Interactions in Drug Discovery. 2008.

22. Bligh SWA, Haley T, Lowe PN. Measurement of dissociation constants of inhibitors binding to $\mathrm{Src} \mathrm{SH} 2$ domain protein by non-covalent electrospray ionization mass spectrometry. J Mol Recognit. 2003; 16 (3): 139-48.

23. Zhang C, Chen H, Guymon AJ, Wu G, Cooks RG, Ouyang Z. Instrumentation and methods for ion and reaction monitoring using a non-scanning rectilinear ion trap. Int J Mass Spectrom. 2006; 255-256 (1-3): 1-10.

24. Wu RF, Huang YD, Chu YQ, Liu ZP, Ding CF. Investigation of Noncovalent Interactions of 18-Crown-6 with Amino Acids in Gas Phase by Mass Spectrometry. Chinese J Anal Chem. 2018; 46 (2): 273-9.

25. Zhang S, Van Pelt CK, Wilson DB. Quantitative determination of noncovalent binding interactions using automated nanoelectrospray mass spectrometry. Anal Chem. 2003; 75 (13): 3010-8.

26. Mayne CG, Saam J, Schulten K, Tajkhorshid E, Gumbart JC. Rapid parameterization of small molecules using the force field toolkit. J Comput Chem. 2013; 34 (32): 2757-70.

27. Vanommeslaeghe $\mathrm{K}$, Raman EP, MacKerell AD. Automation of the CHARMM General Force Field (CGenFF) II: Assignment of Bonded Parameters and Partial Atomic Charges. J Chem Inf Model. 2012; 52 (12): 3155-68.

28. Vanommeslaeghe K, Hatcher E, Acharya C, Kundu S, Zhong S, Shim J, et al. CHARMM general force field: A force field for druglike molecules compatible with the CHARMM all-atom additive biological force fields. J Comput Chem. 2010; 31 (4): 671-90.

29. Schmidt MW, Baldridge KK, Boatz JA, Elbert ST, Gordon MS, Jensen $\mathrm{JH}$, et al. General atomic and molecular electronic structure system. J Comput Chem. 1993; 14 (11): 1347-63.

\section{Литература}

1. Balding PR, Porro CS, McLean KJ, Sutcliffe MJ, Maréchal JD, Munro AW, et al. How do azoles inhibit cytochrome P450 enzymes? A density functional study. J Phys Chem A. 2008; 112 (50): 12911-8.
2. Lupetti A, Danesi R, Campa M, Tacca M Del, Kelly S. Molecular basis of resistance to azole antifungals. Trends Mol Med. 2002; 8 (2): 76-81.

3. Marichal P, Gorrens J, Laurijssens L, Vermuyten K, Van Hove C, 
Le Jeune L, et al. Accumulation of 3-ketosteroids induced by itraconazole in azole- resistant clinical Candida albicans isolates. Antimicrob Agents Chemother. 1999; 43 (11): 2663-70

4. White TC, Marr KA, Bowden RA. Clinical, cellular, and molecular factors that contribute to antifungal drug resistance. Clin Microbiol Rev. 1998; 11 (2): 382-402.

5. Shapiro RS, Robbins N, Cowen LE. Regulatory Circuitry Governing Fungal Development, Drug Resistance, and Disease. Microbiol Mol Biol Rev. 2011; 75 (2): 213-267.

6. Doğan İS, Saraç S, Sari S, Kart D, Eşsiz Gökhan S, Vural İ, et al. New azole derivatives showing antimicrobial effects and their mechanism of antifungal activity by molecular modeling studies. Eur J Med Chem. 2017; 130: 124-38.

7. Jacob K S, Ganguly S, Kumar P, Poddar R, Kumar A. Homology model, molecular dynamics simulation and novel pyrazole analogs design of Candida albicans CYP450 lanosterol $14 \alpha$-demethylase, a target enzyme for antifungal therapy. J Biomol Struct Dyn. 2017; 35 (7): 1446-63.

8. Gao P, Cui YL, Wu RL. Molecular dynamic modeling of CYP51B in complex with azole inhibitors. J Biomol Struct Dyn. 2018; 36 (6): 1511-9.

9. Keighobadi M, Emami S, Lagzian M, Fakhar M, Rafiei A, Valadan R. Molecular modeling and structural stability of wild-type and mutant CYP51 from leishmania major: In vitro and in silico analysis of a laboratory strain. Molecules. 2018; 23 (3). DOI: 10.3390/ molecules23030696.

10. Vijayakumar S, Das P. Structural, molecular motions, and freeenergy landscape of Leishmania sterol-14 $\alpha$-demethylase wild type and drug resistant mutant: a comparative molecular dynamics study. J Biomol Struct Dyn. 2019; 37 (6): 1477-93.

11. Honorato Siqueira T, Martínez L. Molecular simulations of fluconazole-mediated inhibition of sterol biosynthesis. J Biomol Struct Dyn. 2020; 38 (6): 1659-69.

12. Kontoyianni M, Lacy B. Toward Computational Understanding of Molecular Recognition in the Human Metabolizing Cytochrome P450s. Curr Med Chem. 2018; 25 (28): 3353-73.

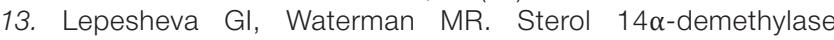
cytochrome P450 (CYP51), a P450 in all biological kingdoms. Biochim Biophys Acta — Gen Subj. 2007; 1770 (3): 467-77.

14. Lepesheva GI, Waterman MR. Structural basis for conservation in the CYP51 family. Biochim Biophys Acta - Proteins Proteomics. 2011; 1814 (1): 88-93.

15. Loo JA. Studying noncovalent protein complexes by electrospray ionization mass spectrometry. Mass Spectrom Rev. 1997; 16 (1): 1-23.

16. Pramanik BN, Bartner PL, Mirza UA, Liu YH, Ganguly AK. Electrospray ionization mass spectrometry for the study of noncovalent complexes: An emerging technology. J Mass Spectrom.
1998; 33 (10): 911-20.

17. Loo JA. Electrospray ionization mass spectrometry: A technology for studying noncovalent macromolecular complexes. Int J Mass Spectrom. 2000; 200 (1-3): 175-86.

18. Ray SS, Singh SK, Balaram P. Sulfonate (ANS) Binding to Proteins. Data Process. 2001; 0305 (01).

19. Zhang S, Van Pelt CK, Wilson DB. Quantitative determination of noncovalent binding interactions using automated nanoelectrospray mass spectrometry. Anal Chem. 2003; 75 (13): 3010-8.

20. Tjernberg A, Carnö S, Oliv F, Benkestock K, Edlund PO, Griffiths WJ, et al. Determination of dissociation constants for protein-ligand complexes by electrospray ionization mass spectrometry. Anal Chem. 2004; 76 (15): 4325-31.

21. Benkestock K. Electrospray Ionization Mass Spectrometry for Determination of Noncovalent Interactions in Drug Discovery. 2008.

22. Bligh SWA, Haley T, Lowe PN. Measurement of dissociation constants of inhibitors binding to Src SH2 domain protein by non-covalent electrospray ionization mass spectrometry. J Mol Recognit. 2003; 16 (3): 139-48.

23. Zhang C, Chen H, Guymon AJ, Wu G, Cooks RG, Ouyang Z. Instrumentation and methods for ion and reaction monitoring using a non-scanning rectilinear ion trap. Int J Mass Spectrom. 2006; 255-256 (1-3): 1-10.

24. Wu RF, Huang YD, Chu YQ, Liu ZP, Ding CF. Investigation of Noncovalent Interactions of 18-Crown-6 with Amino Acids in Gas Phase by Mass Spectrometry. Chinese J Anal Chem. 2018; 46 (2): 273-9.

25. Zhang S, Van Pelt CK, Wilson DB. Quantitative determination of noncovalent binding interactions using automated nanoelectrospray mass spectrometry. Anal Chem. 2003; 75 (13): 3010-8.

26. Mayne CG, Saam J, Schulten K, Tajkhorshid E, Gumbart JC Rapid parameterization of small molecules using the force field toolkit. J Comput Chem. 2013; 34 (32): 2757-70.

27. Vanommeslaeghe K, Raman EP, Mackerell AD. Automation of the CHARMM General Force Field (CGenFF) II: Assignment of Bonded Parameters and Partial Atomic Charges. J Chem Inf Model. 2012; 52 (12): 3155-68.

28. Vanommeslaeghe K, Hatcher E, Acharya C, Kundu S, Zhong S, Shim J, et al. CHARMM general force field: A force field for druglike molecules compatible with the CHARMM all-atom additive biological force fields. J Comput Chem. 2010; 31 (4): 671-90.

29. Schmidt MW, Baldridge KK, Boatz JA, Elbert ST, Gordon MS, Jensen $\mathrm{JH}$, et al. General atomic and molecular electronic structure system. J Comput Chem. 1993; 14 (11): 1347-63. 